\title{
American Futurology as a Sociological problem
}

\author{
Alberto Valdes Cobos \\ Department of Cultural, Demographic and Political Studies \\ University of Guanajuato Campus \\ Guanajuato \\ Rigoberto Sandoval Contreras \\ University of Guadalajara University \\ Center of the Valleys. Ameca \\ Jalisco
}

\begin{abstract}
Summary
This work addresses the concern that has existed to scientifically study the future in the United States and frames it as a sociological problem. However, this concern has matured to become futurology. This analysis focuses on identifying the origins and development of twentieth-century American futurology. It is also interesting to make a critical assessment of Alvin Toffler's futurology, particularly his book The Third Wave, because he predicted some waves of change that the world has experienced in the last hundred years and as one of the main exponents of the functionalist convergence model and technological determinism. Finally, some ethical-political questions are posed to American futurology to show that its future scenarios diverge sociologically from the present and from the economic, technological, political and cultural reality of the third world countries.
\end{abstract}

Keywords: futurology, sociology, technological determinism, third wave.

\section{Introduction}

The American futurology emerged and is consolidated in the twentieth century to give totalizing answers to the most pressing problems of American society. In this sense, the sociological, ethical and political balance becomes necessary to advance in areas of the sociological work such as the analysis of models, agents and factors of social change. While it is true that the concern to know the future of human societies has its roots in the shadows of religious-magical thought and the utopias from distant times, the American futurology is institutionalized after the Second World War through the creation of research centers, congresses, publications and studies such as the technological approach, the global approach and the sociological approach. It should be noted that in the sociological approach we find authors whose works, methods and main ideas have been cataloged as belonging to the post-industrial mainstream of technological determinism characterized by being optimistic about the future of American society and the entire planet: The advent of post-industrial society. An attempt at social prognosis (1981) by Daniel Bell and The shock of the future (1997) by Alvin Toffler. Despite its legacy, futurology today does not enjoy the prestige it had in other times and has been harshly questioned for its ethnocentrism and for ignoring the harsh geopolitical and sociological reality of third world countries and environmental factors.

The objective of this work is to analyze the mythical origins and scientific consolidation of American futurology in the 20th century, examining some of its most representative approaches, critics, authors and works, such as The third wave (1980) by Alvin Toffler. The first section addresses the utopian roots of the scientific study of the future, its approaches and organizations in the United States in the geopolitical context of the Cold War. Next, in the second section, the mythological origins and the scientific institutionalization of American futurology are discussed, as well as their differences with Marxist-Leninist futurology. In the third section The third wave of Alvin Toffler is examined as a sociological model of a-historical function a list convergence. Finally, the fourth section raises some conclusions and questions in the context of a globalized world, threatened by the risks of the global climate change.

\section{The scientific study of the future}

Plato, Campanella, Tomás Moro, Francis Bacon and the French Encyclopaedists, as well as the founders of nineteenth-century sociology, offered utopian visions about desired or possible futures from the present. 
The concern for the future paths that the world may take has been a constant in the history of humanity. However, the scientific character that the study of the future will adopt is a phenomenon that is confined to the 20th century. The forecast was born as a discipline in the United States before than in other countries, at the end of the World War II, when important groups of study and research began to think in the long term (10, 15 or 20 years), like the Institute of Military Aeronautics Studies. In the sixties, groups were created that were mainly occupied with the foresight inside some universities, for example the Hudson Institute; In recent years, many important activities have been developed, like the 2000-year Commission, directed by Daniel Bell (Barbieri, 1993).

In the context of the futuristic fever of the $60 \mathrm{~s}$, Daniel Bell pointed out that in the 20th century there was a change with respect to the interest in the study of the future: The current interest in the future is quite recent. The human race has always tried to consult the stars or read in the entrails of animals in order to know their destiny. In the 1920 s, the idea of prophesying the future took on a festive tone, but for less than a quarter of a century there was little interest in the future. Humanity was worried about a depression on a world scale, was scared by the horrors of concentration camps and fascism and shaken by the turmoil of the war (...) However, in the last five years a flood of writings has been unleashed future and, more importantly, half a dozen institutions have been created with the purpose of examining with seriousness and consistency the problems of the future (...) How can the resurgence of interest in the future be explained? In part, it is undoubtedly due to the seduction of the thousandyear-old figure of the year 2000, which is only thirty years away; Two-thirds of Americans alive today will probably witness the dawn of this chilling year. Elsewhere, it is due to the interest in space adventure, for it is well known that in this generation humanity will reach the moon, and before the end of the century, Mars and Venus will perhaps be reached (Bell, 1969, p.29).

Another factor that played a decisive role for the institutional growth and consolidation of the studies of the future was the methodological development that took place through the collection of temporary statistics, both to trace the direction of the trends, and to extrapolate the probable extensions: "the existence of a trend is not a necessary guarantee of its continuity; nevertheless, the knowledge of tendencies and curves helps us to know better the probable derivations of the future. Finally, with techniques as simple as the Delfos method, we try to exercise certain controls by confronting the known conjectures of one group of researchers with those of others "(Bell, 1969 , p.31).

The scientific study of the future emerged as an autonomous discipline basically in Europe - especially in France and in the United States. His first steps and attempts at foresight had a rather optimistic character. That optimistic accent is present in The year 2000(1969) of Herman Kahn and Anthony Wiener. That trend changed with the Report of the Club of Rome The limits of growth (1972) because this report had a pessimistic tinge, unlike the optimistic futurology of Herman Kahn. The Futurology in the world as a discipline is associated with authors such as Alvin Toffler, Daniel Bell and Herman Kahn, as well as figures like John McHale, Jay Forrester, Aurelio Pecei and Eleonora Barbieri, among others. According to Barbieri (1993) scholars and centers of foresight can be classified, as far as the United States is concerned, according to the emphasis of their studies. This can be technological, global or sociological.

a) Technological: developed after World War II, it was the first focus to develop and prevailed until the midsixties. Very important have been in this type of emphasis futurologists like Herman Kahn, Olav Helmer and Joseph Daddarío.

b) Global: has been dominant in the sixties, and in these studies it is worth noting researchers such as Jay Forrester, Denis Meadows and Donella Meadows with their classic The limits of growth (1972), where their authors handle global variables such as population, natural resources, arable land, industrialization and pollution.

c) Sociological: corresponds to a group of North American scholars who express the concern for the foresight between the second half of the sixties until today. Among them are John McHale, Alvin Toffler and Daniel Bell.

The international organizations that have dealt with foresight are diverse, as are their approaches. Among them is the World Federation of Future Studies, founded in Paris, at the UNESCO headquarters in 1973.

Another example is the Club of Rome, founded in 1968 by Aurelio Pecei and Alexander King; this organization played a very important role in the seventies and eighties raising the level of awareness of researchers and institutions dedicated to the studies of the future. 
In addition, intergovernmental organizations have shown interest in foresight studies, including UNESCO, UNDP, UNITAR, OECD, ECLAC and the United Nations University (Barbieri, 1993).

For example, the World Future Society -according to the bulletin no. 17 of the Mexican Chapter (2000) -, was founded in 1966 in the United States by scientists of various professions with a common goal: the serious study of the future. Currently the WFS is recognized as the most important organization of the American Union and the world on future studies. According to the WFS / CAMEX editors, the WFS identifies itself as a non-profit, educational and scientific organization based in Washington, DC, which acts as a neutral center for ideas in more than eighty countries, actively participating in its activities. programs and activities.

The World Future Society is a "neutral organization in political matters" that has the sympathy of leaders of the United States and globally, as we can see in a message from former President Bill Clinton: "I urge the members of the World Future Society, to work with vision and energy developing creative strategies to fulfill the promise of the future and face constructively the challenges that inevitably accompany the change with the benefit of their insight we can create a future of peace, prosperity and freedom "(bulletin no.17, Mexican Chapter, 2000). This international society publishes a large number of periodical publications and books, supports its established chapters around the world, holds a series of conferences and an annual assembly is considered as the forum that provides opportunities to listen to the most notable futurologists in the field international. For example, on July 29, 1999, the 9th Annual Assembly of the World Future Society was held in Washington, DC under the slogan "Frontiers of the 21st. Century ", an event that brought together more than 1200 experts in the study of the most relevant issues related to the future of humanity. Researchers and scientists from different professions and specialties worked with a diversity of topics such as the future of Europe, new technologies, employment, Latinos in the US, transnational corporations, social and values change, globalization, communities, agriculture and food, education, the ecological environment, economy and finances, public services and many other topics.

At the end of World War II, the need to foresee the future intensifies: centers, universities and journals that specialize in the subject arise both in the West and in Eastern Europe. In the middle of Cold War, studies on the future of socialism and capitalism are necessary for geopolitical reasons. The ideological struggle was extrapolated to a struggle for the future: increase and expand political influence; Overcoming the conquests of the present was the slogan of the Marxist-Leninist nomenclature. After all, the two ideologies divinized the future as no other ideology had done in history, in particular the Soviet Marxist-Leninist one. However, there was also futurophobia for the threats and dangers that could trigger the arms race between the United States and the Soviet Union.

Currently the future studies (futures studies, Anglo-Saxon term) are developed both in the doctrinal field and in practical applications, which include institutes and research centers such as Cellule de Prospective, Futures Studies, Futuribles, Global Busines Network (GBN), Institute for the Future, Institute of Prospective Technology (IPTS), International Institute of Applied Systems Analysis, OECD International Future Program, Resources for the Future Research, Strategic Futures International, The Copenhagen Institute for Futures Studies, The World Future Society and World watch.

\section{Origin and development of American futurology in the 20th century}

Where does futurology come from? Who was the first futurologist of the West? What were the political positions in the futurology of the seventies? Where does the optimism that drove Western futurology come from, particularly the American one? What are some of the criticisms that have been made to futurology in general? Futurology as eschatological mythology arises in Europe and as a science it is consolidated and developed in the United States. According to André Reszler (1984), The myth of the three ages, which is concealed behind the historicist representation of the critical and organic eras of humanity, is the late triumph of the millenarian prophecies of Giacchino da Fiore. Fiore is perhaps the first futurologist in Europe to announce the promise of a thousand years of happiness and harmony. The anticipatory structure of their prophecies is the distant model of the unilinear philosophies of history and of the scientific representations of the idea of progress (...) our sociological and ideological mythologies of salvation come from the prophetic system of Giacchino da Fiore. The insightful Calabrian abbot is the first futurologist of the West (...) reading in historical key of the Bible allows Giacchino to glimpse three ages in the interwoven plot of secular history and sacred history. The first age is the Father, characterized by fear and servitude. The second is the Son, marked by faith and filial submission. The third, the Holy Spirit, the age of love and the final liberation of the spirit in its fullness. 
Giacchino's list of "disciples" in Germany includes the names of Schelling, Fichte, Hegel and even Marx: who does not recognize the debt with his predecessors In France, the tripartite prophecy of Giacchino influences Comte through Saint-Simón (Reszler, 1984, p.65).

Whom talks about the future is forced to tell a story. The less poets of contemporary futurists, the American technicians of the future, are dedicated to building relationships of facts, vicissitudes, that are, true epic tales. To speak of the future, the poet must remember the myth of Prometheus, which is the first myth of Marx. It is not surprising that Marx was in love of the future, and he recurs unconsciously to the myth. The myth fecundates its philosophy of history, gave it coherence and prophetic accents (Rezler, 1984).

As a science, futurology is promoted and expanded in the most futuristic country: The United States, where the World Future Society resides. The industrial and scientific development operated in the first half of the twentieth century, among other things causes that the work of those who are engaged in prospecting the future lose the fictional nature of the utopian writings (we can found this in Cabet, Owen, Fourier, Volney and Campanella), taking a look of authentic probability, becoming a work in which the scientific replaces the imaginative. Barbieri, by fhis self (1993, p.56) assumes futurology as follows: "The term futurology, described by Ossip Flechteim is understood as an investigation of the logic of the future, and this deserves special mention. It is a true and proper science that it is proposed to project the present in the future, one could say that it tries to specify evolution and distinguish what is inevitable from what can be prevented and whose consequences can be influenced ". OssipFlechteim defines futurology as a science that performs integrative functions that until now had been in the field of philosophy and, in part, of sociology (Kosolapov, 1980).

In the decade of 1960 the debate arose around if the technique was the one that created the values or if they were those that created to the technique, in relation to this type of problems, some authors raised the emergence of futurology: A new discipline that has numerous organizations that bring together hundreds of specialists from very different fields, who converge in a moral point of view (...) the First International Conference of Futurologists was held in Oslo (Norway), in 1967 , and specialists from more than a dozen countries participated (...) Futurology occupies a position that is between those humanists such as Ellul, Marcuse, Juenger and even Mumford, etc., with clear prejudices against technological development, and utopists like Clarke, absolute glorifier of the technique and prophet of the fantastic (...) the task of futurology is the planning of the future, in its dual physical and moral ecology, from the present realities. What futurology proposes is to eradicate definitively the central thesis of the old economic liberalism, which in the words of Adam Smith the "individual, in pursuing his own interest, frequently promotes the general interest more effectively than when it is the general interest that pursues (...) This famous doctrine of the invisible hand has been at the foundation of the industrial development of capitalism. The result has been industry, wealth, scientific and technical progress, and as byproducts: pollution, demographic pressure, economic exploitation, a crude idea about life - the law of the jungle sanctioned by social Darwinism - and in the last decades, as a consequence of the acceleration of the industrial and technological rhythm, an anguishing pressure on values, which forces to make readjustments and readaptations so fast that the individual is deranged, without a moral foundation to lean on (Lloris, 1974, pp. 47 -49).

According to the Marxist critic V. Kosolapov, "the existence of a materialist interpretation of history prepares the way for a scientifically prediction of the future course of the social development (...) the past, the present and the future of human society share the same common laws that govern historical progress "(Kosolapov, 1980, p.63). In his book Humanity in the year 2000, Kosolapov makes a sharp separation between"bourgeois futurology"and "Marxism-Leninism", especially in the chapter two, particularly the section entitled "Bourgeois futurology, an attempt to solve the problem from the other side." So much is the Marxist-Leninist eschatology of this author who does not hesitate to predict the extinction of capitalism in chapter two of his book: "Capitalism as a piece of museum." Based on quotations from Marx and Lenin, Kosolapov does not stop criticizing "bourgeois futurology" and keep "predicting" the collapse of capitalism in charge of the laws of historical materialism: "the emergence of bourgeois futurology represents an attempt to find a way to save capitalism and adapt it to the requirements of the scientific and technological revolution" (Kosolapov, 1980, p. 63).

In the middle of the Cold War, Kosolapov made echoes about the Futurist Manichaeism by describing the ideological polarization in the following terms, The main concepts of bourgeois futurology are used as weapons against Marxism-Leninism, which predicted the transition of the totality of humanity from capitalism to communism. In fact, futurology as such came to public attention during the struggle of bourgeois ideology against communism. 
The rise of the predictions it has explored about the capitalist world has an obvious ideological purpose, which is to impose the idea that it is possible, in the foreseeable future, to build an opulent society without undermining capitalism (Kosolapov, 1980, p. 64).

However, it should be remembered that Western futurology, particularly the American one, is indebted to political liberalism, while "Soviet or proletarian futurology" was inspired by Marxism-Leninism. The two currents were opposed to tradition (or the past) and their batteries are directed to the future. Both were rooted in the fever for progress. Both stressed the struggle for the emancipation of human societies: one trend "affirmed" political and economic freedoms in capitalist democracies and the other "promised" equality and "suppressed" political and economic freedoms in socialist societies; in addition, the two ideas are heirs of the Enlightenment.

In the same way as Kosolapov, the American sociologist Irving Louis Horowitz (1980) also attacked American futurology. From the seventies of the last century, Horowitz mocked about the American futurology, in the same way that other left social scientists did. In reviewing the state of affairs in the United States, Horowitz found that one of the pleasing fictions of orthodox sociologists was that science is modern, opposed to journalism that is belated. However, he suspected that sociology, like all the other disciplines that deal with the life and death of human beings, was also a victim of its worst examples and conventions. The cult of futurism, not only in its refined sociological expressions, but also in its pedestrian ideological forms, exhibited many of these tendencies. Now, what were the dangers of oracular or futuristic sociology?

A strange role played by sociologists in the United States is like oracles. Sociologists have assumed this role, not only because of the decline of the faith from the organized religion, but also because they still feel the need for a generalized wisdom about salvation as something collective, terrestrial, imminent, total and miraculous. Out of the reluctance or modesty of others, sociologists become the new theologians, in a universe where God is supposed to have died, and sometimes, it is supposed to have been killed by the social scientists. They respond to a felt need for realistic and comforting responses in a period of the history in where the theological tradition does not offer the answers that apparently is required by a highly industrialized and modernized society (Horowitz, 1980, p.).

In the same way that Reszler is dedicated to search into the basement of the history of modern thought and futurology, Horowitz does the same about the futuristic sociology of his country, In contrast to the theologian, futurologists tend to exaggerate the differences with the past; they have the seemingly insatiable need to distinguish our epoch from all the others, as in the case of Alvin Toffler when he speaks of the "new superindustrial society" or of the third wave. We live only in the current moment, and only at this moment in space. Therefore, it is not surprising that futurologists want to see the current moment in special terms, even if such terms are expressed in a somber language of the crisis and convulsion (...) sociology and futurology are a consequence of the same problem: our discomfort and restlessness in the present moment. From this point of view, futurology, or the science of looking at the future, is based on the same feelings and the same psychic needs of intellectuals who insist on studying the past to face the present (Horowitz, 1980, p. the italics is ours).

\section{The futurology of Alvin Toffler: a critical balance of The third wave}

Alvin Toffler was born in 1928 in New York and died in 2016 in Los Angeles California. He graduated in Literature from the University of New York where later received his doctorate in Arts, Law and Science, and although he did not develop an academic career, he is an honorary doctor by several universities. Throughout his professional life Toffler had an outstanding performance as a journalist in publications such as Fortune, Horizon, Life, as well as a lecturer. He was an advisor for important companies and foundations such as Rockefeller Brothers Found and IBM Corporation. In 1996, he founded, together with Heidi, his sentimental partner, Toffler Associates, an international consultancy that works with political leaders, countries, companies and NGOs around the world.

As an analyst and researcher of the transformations that the world has been experiencing in the last hundred years, Toffler investigated the trends and future-bearer events, as well as the imperative reforms required to adapt to them. In this sense his work, described by his critics as too literary and impressionistic, consists of several titles that have become bestsellers at a global level such as The Shock of the Future (1970), The Third Wave (1980) and The Change of Power (1996). Although, it also has other publications such as Consumers of Culture (1987), Progress and premises (1983), The flexible company (1985), The creation of a new civilization: the politics of the third wave (1996), The wars of the future (1995) and The Wealth Revolution (2006). 
In this section we will review the main premises of The third wave and we will question some of its implicit sociological assumptions. The third wave is a book that can be seen as a complement to The shock of the future, since it places its focus on the directions of global change and expands the evolution of the Tofflerian thought, while deepening its theoretical premises.

The most important thesis of The Third wave was that the industrial world society, including the capitalist and socialist countries, wass in the middle of a general crisis. With the theoretical construct and the metaphor of the "Waves", Toffler argues that the agricultural revolution from 10,000 years ago started the first wave of change in human society. Toffler takes up the metaphor of the wave of authors like Norbert Elías and Frederick Jackson and applies it to the change that is taking place in today's civilization. For Toffler, the metaphor of the "wave" is extremely fructiferous because it allows him to organize large masses of very diverse information. However, Toffler clarifies that "even the most powerful metaphor is only capable of transmitting a partial truth", that is, "no metaphor tells the story from all sides, and because of that, no vision of the present, or the future,' 0 can be complete or definitive. "

The industrial revolution that began about 300 years ago, and that brought with it a tide of political and social struggle, sent a second wave of change that covered the entire planet. And now, in Toffler's opinion, there is a resurgence of a new critical transition, while contemporary trends in technology, economics, politics, family life, the use of energy and other spheres of life, give entrance to a third rupture of the civilization: a transformation to the forms and social schemes of the third wave.

How can we describe The third wave model? Toffler begins in a inductive way describing what all civilizations have in common.

1) A "Technosphere". An energy system, some method to produce goods and services, and a distribution system.

2) A "Sociosfera". A set of social institutions, for example, the civilization of the second wave has the family, the school, the company, the political party, etc.

3) An "Infosphere". A system for the communication of the information generated.

4) A "Biosphere". A place where different societies work, in which the conditions may vary with the passage of time.

5) A "Powerhouse". Where the authority is assigned through political institutions, both formal and informal.

6) A "Psychosphere". A sphere of intimate relationships of subjectivity and personality.

Putting all together and horizontally, Toffler systematically examines their interactions, both within and between these diverse spheres of action in each of the three waves or civilizations. For Toffler, the United States is the country where there is a collision between the second wave and the third wave. The conflict between groups of the second and third waves constitutes the central of the political tension.

From the Toffler an perspective in the countries of the second wave operate six principles that sustain the industrial society: standardization, specialization, synchronization, concentration, maximization and centralization. All these principles led to the rise of bureaucracy and massification. The philosophical conception or Indusreality (the nature like object of exploitation, the principle of the progress, the theory of the evolution and the causality and the idea of the time in pieces that is extended in straight line from the past to the future) in that the second wave is based and is in question before the birth of the civilization of the third wave.

The civilization of the third wave in Toffler represents an effort to go beyond socialism and capitalism, as they were known in the last three decades of the 60s and 70s. It is a way of going beyond the left and the right, of the democrats and the republicans of the United States and taking a place above the political and ideological positions, because in his opinion this dichotomy does not work or is no longer useful to visualize and to realize the changes that were taking place in society due to the "surprise arrival" of the new civilization.

Now, what factors or agents determine the social change in The third wave of Toffler? One of the current issues in the American functionalist sociology is the issue of social change, as well as its agents and factors that originate it. In a changing society such as the United States, it is not uncommon find an infinite of sociological mainstreams and theories to try to explain it. In this regard, some authors point out that several deterministic models have been invented to explain social change. A deterministic model is one that uses a single force or determining variable that affects the others and consequently produces the so-called social change and as examples of these deterministic models include a) technological determinism; b) economic determinism; c) political determinism and d) ideological determinism (Croos, Elliot and Roy, 1980). 
The technological determinism is the idea that social development is almost totally determined by the technological changes that a society invents, develops, adopts, is one of the most common models in the technology-society relationship. In this model, societies are classified according to the stage of technological development they have reached, from the ages of "stone", "bronze", "iron" and "steam" from the past to the "atomic" age or the "computer" "in present time (Croos, Elliot and Roy, 1980, p.37).

For the critics of Toffler the deterministic relation technology-society is an analytical pattern present in the work of him, for that reason they have not hesitated to qualify him as a "popularizer" of the deterministic technological model, especially when he points out in The Shock of the Future that the problems of personal and social adaptation in the face of technological changes are apparently beyond the reach of human control. For Toffler technology is a driver of change in society while knowledge represents its fuel. However, in The Third Wave, Toffler moves away from the deterministic technological model and approaches a convergence model to explain social change. The convergence model starts from the assumption that social events and phenomena are interrelated and not isolated, this means, you can not have an economic change (inflation, falling stock markets) without changes in family life, energy and ecosystems. All these elements are connected by a complex feedback bond. The third wave is an effort to discover that there is no single driving force in history (such as the technological determinism adopted in The Shock of the Future), but that other forces or tendencies coexist and converge to produce major changes at the global level.

Some of the criticisms that have been raised to The third wave analytical model are: a) the convergence theory falls in the functionalist theory, the first problem it presents is its a-historical vision, since it presents universal and generalizing abstractions; b) the tendencies to integration are so broad and general that its conclusions are mechanical and extremely simplistic and it loses sight of the differences between the United States and the USSR, for example; c) the conflict must have its theoretical component and its empirical component. Toffler basically refers to the theoretician under an abstract dimension. This would be correct if it was referred to the concrete and empirical data; d) will it be possible to build the society of the third wave? Toffler starts from an unreal model because it does not contemplate the structural conditions of societies; in addition, the society of the future built in order to achieve happiness and well-being, is an ideal approach, these values have little to do with the social, political, cultural and economic problems of different societies (Calvo, 1992) .

\section{Criticisms of American futurology}

For our part, the criticisms and observations that we can make to American futurology are the following:

A) While it is true that futurology became a science to predict the changes that await human societies, it was not the same to say that this science of the future has privileged a technological determinism at all costs, disdaining the role that factors political, economic and cultural have played in shaping the future. Certainly, a technological determinism that is not justified in front of a world system where societies with unequal levels of development coexist and because that technological determinism has caused a series of perverse and irreversible consequences in the biosphere and in human societies, giving rise to a global risk to the society that is questioning the survival of humanity in the 21 st century.

B) The models and forecasts of futurology have only taken into account the existence of a single type of society: societies where futurists reside, first world societies (super-industrial, third-wave or post-industrial) where computers, cybernetic, biotechnology and other technologies have been incorporated into a production process without limit, forgetting the harsh sociological reality of third world countries, semi-industrialized, underdeveloped, where the predictive reach of Tofflerian futurology, for example, is not viable even like a metaphysical aspiration. Although many Think tanks, the World Bank and organizations such as the World Future Society recruit hundreds of futurologists with the purpose of foreseeing, planning and constructing scenarios to shape the society of the future, we must not forget that nowadays and in spite of a process of galloping globalization, humanity is dragging down heavy burdens from the past such as social inequality, poverty, xenophobia, nationalism, terrorism and global climate change.

It should be noted that what American futurology has done has been "to condition a future tailored to the social, socioeconomic, political and technological structure of modern first world societies".

C) Another criticism that has been made to American futurology is that the change in attitude that accompanied the institutionalization of ecology reverberated in futurology, because by the eighties it was evident that its hour of triumph had passed and its scientific pretensions were not immune to the environmental criticism, which accused her of being a pseudo-philosophy of history made it to the measure of technically advanced 
societies. Apart from the fiasco of its forecasts, the American futurology suffered the competition of new predictors that disputed the public attention. To this were added the attacks from the Third World, as futurology was accused of looking at the navel and thinking about tomorrow in Western terms, since from its conception futurology had been developed according to the needs of its sponsors: military apparatus, large companies and governments of the North (Francescutti, 2003).

According to some detractors, futurists no longer predict. Everywhere reigns the diffuse feeling of the loss of the future. The future is not necessarily development. Onward, the future is called uncertainty (Morín and Briguitte, 1993). However, in the American futurology of the second half of the 20th century, writers, physicists, sociologists and futurologists such as Herman Kahn, Anthony Wiener, Alvin Toffler and Daniel Bell, have been cataloged as members of the post-industrial trend regarding the central ideas, the methods, the attitudes, the contributions, the representative works and the key words (Bas, 1999):

- Central idea. This current of thought establishes a direct relationship between technological progress and economic and social development. Under this perspective, the future comes about through technological change, which can be accelerated and dominated by foresight and planning. We would be talking about technological determinism.

- Method. The method of analysis used is intellectual reflection based on the extrapolation of trends, with special attention to technological innovations.

- Attitude. Optimistically, explicitly or implicitly (bad news is good news). Technological progress always involves economic and social development; Moreover, social development depends on the degree of technological development.

- Reference works. H. Kahn and A. Wiener, The Year 2000 (1967); A. Toffler, The shock of the future (1972) and The third wave (1980); D. Bell, The advent of post-industrial society (1973).

- Contributions. Induction to the reflection on the future, although too literary.

- Keywords. Technology, modernization.

\section{In conclusion}

Futurology has gone through different processes, from a utopian conception in its origins to its scientific institutionalization. Currently it is a vein of analysis for sociology because it has become established as a disciplinary field to raise research topics that can encourage researchers of different profiles such as physicists, mathematicians, engineers, sociologists or anthropologists, about what has happened in the world and its civilizations, in a comprehensible and predictable context, to answer the question of what can happen. It is not an approach that should be taken lightly, because it invites us to think about possible long-term future scenarios of the continuity of human societies.

The history of humanity shows that civilizations have had to modify their lifestyles and human relationships have become more complex, due to technological factors, but also to economic and political interests of the elites and power groups that manage to impose hegemonic guidelines, affecting the histories, the common goods and the welfare of other sectors and subaltern social classes. Considering it, it is possible to influence and modify the way of inhabiting the planet earth, as well as social structures, because now it is clear to us that the earth is a shared space and that it is not owned by a few, therefore, the actions that generate the elites will impact in some way or another on the future of human societies.

Thinking and rethinking the future from a sociological perspective has made it possible to identify the social changes that human societies have gone through and to reflect on where they can go, on what factors we have to pay attention and provide proactive solutions to the major social problems. While there are theorists who have given a sociological guideline, it is still a young approach, given that social phenomena are endless and continually emerge, it would not be enough to investigate the origin, but now we should focus on proposing where they are going, more even, till where is it possible to direct the future if human relationships are diverse and change over time.

With the futurology, sociology has broadened its theoretical-methodological work to investigate and reflect on the present of human societies to answer questions such as What social changes will societies experience in the year 2050? Will robots replace humans? Will we reach the limits of growth? How will social institutions such as family, school, media, religion or economy change in the next 200 years? 
Natural resources, labor, population, technology and globalization seem to be categories of elementary analysis to understand transnational interrelations, as well as the journey of societies involved in a industrial and postindustrial dynamics to adapt to a world of finite natural resources and infinite human consumption needs, with risks of catastrophes due to global climate change.

Where are we going? It is a question of scientific, political and ethical order for the American futurology and for the futurology of other countries. Construction of the futures from the realities and the present of the rich countries or of all the countries of the world? What should be considered to explain the processes of long-term social change or the possible collapse of all human societies? The environmental crisis, new technologies, neoliberal globalization, social movements, terrorism or wars? Will we remain anchored to totalitarian utopias that have already failed in the 20th century? While futurology began as a philosophical concern to think about the future of the human societies, this concern does not seem to have been abandoned altogether, because it is still pertinent to ask ourselves: Where is humanity going and how to build a satisfactory future for all that not put in question the survival of human societies? Answering this question implies making a rigorous sociological analysis, identifying the economic, political and scientific-technological megatrends, as well as the risks, dangers and threats of global warming.

\section{References}

Barbieri, E. (1993). La previsión humana y social. México: Fondo de Cultura Económica.

Bas, E. (1999). Prospectiva. Herramientas para la gestión estratégica del cambio. México: Ariel.

Bell, D. (1981). El advenimiento de la sociedad pos-industrial. Un intento de prognosis social. Madrid: Alianza Editorial.

Bell, D. (1969). Introducción. En. H. Kahn y A. Wiener. El año 2000 (pp. 25 -33). Madrid: Revista de Occidente.

Calvo, B. (1992). AlvinToffler: la tercera ola. En H. Cuadra (coord.). Crónicas sobre utopías (pp. 31-53). México: Universidad Autónoma Metropolitana Unidad Xochimilco.

Croos, N; Elliot, D y Roy, R. (1980). Diseñando el futuro. México: Gustavo Gili.

Francescutti, P. (2003). Historia del futuro. Una panorámica de los métodos usados para predecir el porvenir. Madrid: Alianza Editorial.

Horowitz, I. (1980). Ideología y utopía en los Estados Unidos 1956-1976. México: Fondo de Cultura Económica.

Kosolapov, V. (1980). La humanidad en el año 2000. México: Nuestro Tiempo.

Lloris, M. (1974). El siglo XXI. Barcelona: Salvat Editores.

Morín, E. y Brigitte, A. (1993). Tierra-patria. Buenos Aires: Ediciones Nueva Visión.

Reszler, A. (1984). Mitos políticos modernos. México: Fondo de Cultura Económica.

Toffler, A. (1997). El shock del futuro. Barcelona: Plaza y Janes.

Toffler, A. (1980). La tercera ola. Barcelona: Plaza y Janes.

WFS-CAMEX A.C. (2000). ¿Qué es la WorldFutureSociety Capítulo Mexicano A.C.? Boletín $\mathrm{N}^{\circ}$ 17, julio. México. 